\title{
Sublethal effects of emamectin benzoate on life table parameters of the cotton leafworm, Spodoptera littoralis (Boisd.)
}

\author{
El-Sayed Mokbel ${ }^{*}$ a and Amal Huesien ${ }^{*}$
}

\begin{abstract}
Background: The cotton leafworm, Spodoptera littoralis (Boisd.), is a serious economic pest in Egypt. Pest control depends mainly on chemical control with several pesticides include conventional and modern insecticides. Comprehensive analysis of pesticides impacts needs to investigate sublethal effects in addition to lethal effect.

Results: In the current study, the leaf-dip bioassay method was used to evaluate emamectin benzoate (EMB) sublethal concentrations. Results showed that EMB proved high toxicity against $S$. littorals with $L C_{50}$ value of 0.019 mg liter ${ }^{-1}$. Life table analysis showed that treatments with $L C_{5}$ and $L C_{15}$ prolonged larval period, mean longevity of males and females, mean generation time (T), doubling time (DT), adult preovipositional period (APOP), and total preovipositional period (TPOP) compared with control. On the contrary, net reproduction rates $\left(R_{0}\right)$, intrinsic rates of increase $(r)$, finite rate $(\lambda)$, fecundity, gross reproductive rate (GRR), and relative fitness were decreased compared to control.

Conclusions: The current study clarified that sublethal concentrations of EMB induce adverse effects and suppress the population growth of S. littorals. Our results would be useful to assess the overall effects of EMB on S. littorals and can contribute effectively in pest management.
\end{abstract}

Keywords: Cotton leafworm, Emamectin benzoate, Sublethal effects, Life table parameters

\section{Background}

The cotton leafworm, Spodoptera littoralis (Boisd.) (Lepidoptera: Noctuidae), is a key destructive polyphagous insect pest (Hosny et al. 1986). This pest attacks several plant species belong to about 40 plant families (Pineda et al. 2007). Hosts overlapping contribute to high population densities of the pest and consequently economic losses throughout attacking various plant vegetative parts (Osman and Mahmoud 2009). So, several insecticides include emamectin benzoate were recommended to combat the pest (Egyptian Agricultural Pesticides Committee 2019).

Emamectin benzoate (EMB) is a member of the avermectins group, acts as gamma-aminobutyric acid

\footnotetext{
*Correspondence: sayedmokbel@yahoo.com; himahamza2010@gmail.com Central Agricultural Pesticides Laboratory, Agricultural Research Center, Giza 12618, Egypt
}

(GABA)-gated chloride channels agonist. EMB increases chloride ion flux in neuromuscular junction, causing irreversible paralysis and finally death (Ishaaya et al. 2002). EMB proved high efficiency against S. littoralis larvae (Mokbel et al. 2017, 2019). Assessment pesticide sublethal effects are necessary to assess the overall impact of this pesticide against the target pest (Stark et al. 1997). Sublethal effects draw upon insecticide class and pest species (Desneux et al. 2007). Sublethal amounts of pesticides can affect population growth parameters, feeding behavior, and insect bodies nutrient content (Rehan and Freed 2015; Xu et al. 2016). Barrania (2019) clarified that treating 2nd instar larvae of $S$. littoralis with $\mathrm{LC}_{5}$ and $\mathrm{LC}_{10}$ of emamectin benzoate affected larval weights, larval duration, pupation, pupal mean weight, and adult emergence rates.

\section{Springer Open}

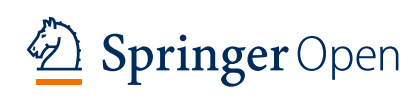

(c) The Author(s). 2020 Open Access This article is licensed under a Creative Commons Attribution 4.0 International License, which permits use, sharing, adaptation, distribution and reproduction in any medium or format, as long as you give appropriate credit to the original author(s) and the source, provide a link to the Creative Commons licence, and indicate if changes were made. The images or other third party material in this article are included in the article's Creative Commons licence, unless indicated otherwise in a credit line to the material. If material is not included in the article's Creative Commons licence and your intended use is not permitted by statutory regulation or exceeds the permitted use, you will need to obtain permission directly from the copyright holder. To view a copy of this licence, visit http://creativecommons.org/licenses/by/4.0/. 
Life table parameters indicate population growth rates and can clarify the insecticide sublethal effects on insect population (Rahmani and Bandani 2013; Chi and Getz 1988). These parameters can be used to delay resistance development, combat pest resurgence, and use pesticides in optimal ways (Kareiva et al. 1996; Forbes and Calow 1999; Zanuncio et al. 2005; Lashkari and Sahragard 2007; Rezaei et al. 2007; Desneux et al. 2007). Age-stage, two-sex life table analysis can overcome certain drawbacks in other life table methods analysis (Chi and $\mathrm{Su}$ 2006). Agestage, two-sex life table procedure was used to investigate these parameters in several insect pest species including mirid bug, Apolygus lucorum (Meyer-Dür) (Zhen et al. 2018), peach fruit moth, Carposina sasakii Matsumura (Lepidoptera: Carposinidae) (Quan et al. 2016), and chive gnat, Bradysia odoriphaga (Zhang et al. 2014a, 2014b).

The present study aims to investigate sublethal effects, to project pest population growth, and to evaluate emamectin benzoate use against $S$. littoralis. These findings can contribute in developing effective pest management measures.

\section{Methods}

\section{Insects and insecticides}

Laboratory colony of $S$. littoralis was reared in Central Agricultural Pesticides Laboratory (CAPL), Agricultural Research Center, Dokki, Giza, Egypt. Spodoptera littoralis has been reared on fresh castor bean (Ricinus communis) leaves, maintained at a constant temperature of $25 \pm$ $2{ }^{\circ} \mathrm{C}$, relative humidity $(\mathrm{RH})$ of $65 \% \pm 10$, and a photoperiod of $14 \mathrm{~h}: 10 \mathrm{~h} \mathrm{~L}$ : D. Emamectin benzoate formulation used was Biolarve 5\% EC (CHEMVET, China).

\section{Bioassays}

The leaf dip bioassay method was used to determine concentrations of mortality response. A stock solution was prepared from insecticide formulation by using tap water. Five concentrations with five replicates in each concentration were used to obtain the toxicity line. Castor bean leaves were dipped into insecticide solution for $30 \mathrm{~s}$ and allowed to dry for a half-hour. Leaves dipped into tap water served as control. Each replicate includes ten 1st instar larvae in Petri dishes $(5 \mathrm{~cm})$ where the treated leaves were placed. Then, Petri dishes containing treatments were kept in the aforementioned rearing chamber until mortality was scored after $24 \mathrm{~h}$. Larvae were considered dead if they failed to exhibit coordinate movement when probed with a soft camel hairbrush.

\section{Life table construction}

Life table experiment involved three treatments (untreated control, $\mathrm{LC}_{5}$, and $\mathrm{LC}_{15}$ ). From each treatment, one hundred 1st instar larvae of S. littoralis were taken, and each larva was considered as one replicate. Larvae were kept in Petri dishes $(5 \mathrm{~cm})$ in the aforementioned rearing chamber. The larval stage was reared on fresh castor bean leaf disks which were replaced daily to avoid fungal growth. Larval mortality and duration were recorded individually. When larvae reach the prepupae, it weighted for a final time. Also, pupae weight, duration, adults' emergence, and female ratio were determined. After adults' emergence, a female was paired with a male to be a couple. Each family was kept in a glass jar with a vertical hanging tissue paper for egg laying. Eggs were collected daily by eliminating the tissue paper daily until female death. The fecundity was recorded as the average number of eggs per female.

\section{Data analysis}

Larval mortality was corrected according to Abbott's formula (Abbott 1925) and then subjected to the probit analysis (Finney 1971) to determine EMB lethal concentrations $\left(\mathrm{LC}_{50}, \mathrm{LC}_{15}\right.$, and $\left.\mathrm{LC}_{5}\right)$ using EPA probit analysis version 1.5. Age-stage, two-sex life table analysis was used to derive biological aspects and population growth parameters. Mean values and standard errors were obtained throughout the bootstrap method included in the TWOSEX-MS chart program (Chi 2012). Significant differences between mean values of pre-pupae weight, pupae weight, and pupae period were analyzed throughout the ANOVA method using the SPSS program at ( $P$ $<0.05)$ (Cor, IBM SPSS 2016). Survival rate $\left(S_{x j}\right)$, reproductive value $\left(V_{x j}\right)$, survival $\left(l_{\mathrm{x}}\right)$, fecundity $\left(m_{\mathrm{x}}\right),\left(f_{\mathrm{x} 4}\right)$, and $\left(l_{\mathrm{x}} m_{\mathrm{x}}\right)$ curves were constructed using GraphPad Prism 7. The relative fitness of the treatments was calculated according to Shen et al. (2017) as follows: Relative fitness $=R_{0}$ of the treatment $/ R_{0}$ of the control. Where $R_{0}$ represents the net reproductive rate.

\section{Results}

Toxicity of emamectin benzoate on the 1st instars larvae of S. littoralis

Emamectin benzoate exhibited high toxicity against the 1st instar larvae of $S$. littoralis with $\mathrm{LC}_{50}$ value of 0.019 mg liter ${ }^{-1}$. In extension, concentrations that caused 5 and 15 percent mortality were $0.001 \mathrm{mg} \mathrm{liter}^{-1}$ and $0.003 \mathrm{mg} \mathrm{liter}^{-1}$, respectively (Table 1 ).

\section{Sublethal effects of EMB on biological characteristics of $S$. littoralis}

The effect of EMB sublethal concentrations on biological characteristics were investigated (Table 2). Sublethal treatments significantly increased larval period, pupae period, mean longevity (days), mean longevity of females (days), adult pre-ovipositional period (APOP), and total preovipositional period (TPOP). In contrast, it reduced significantly pupae period, ovi-days, and fecundity. 
Table 1 Toxicity of emamectin benzoate to the first larvae of Spodoptera littoralis

\begin{tabular}{|c|c|c|c|c|c|c|}
\hline \multirow[t]{2}{*}{ Insecticide } & \multicolumn{3}{|c|}{ Concentration (mg (ai) liter $\left.{ }^{-1}\right)(95 \% \mathrm{CL})^{\mathrm{b}}$} & \multirow{2}{*}{$\begin{array}{l}\text { Slope } \pm \\
\text { SE }^{\mathrm{a}}\end{array}$} & \multirow[t]{2}{*}{$x^{2 c}$} & \multirow[t]{2}{*}{$d f^{d}$} \\
\hline & $\overline{\mathrm{LC}}$ & $\mathrm{LC}_{15}$ & $\mathrm{LC}_{50}$ & & & \\
\hline EMB & $0.001(0.00-0.002)$ & $0.003(0.001-0.005)$ & $0.019(0.013-0.027)$ & $1.35 \pm 0.19$ & 5.75 & 3 \\
\hline
\end{tabular}

${ }^{\mathrm{a} S t a n d a r d}$ error

${ }^{\mathrm{b}} 95 \%$ confidence limits

'Chi-square value $\left(X^{2}\right)$

${ }^{\mathrm{d}} \mathrm{df}$, degrees of freedom

Furthermore, pre-pupal and pupal weights were decreased significantly compared with controls. Sublethal treatments prolonged the developmental duration of larval stages from ( 15.71 days) in control to 16.15 , and 16.26 days for $\mathrm{LC}_{5}$ and $\mathrm{LC}_{15}$, respectively. Sublethal effects continued into the adult stage, adult preovipositional period (APOP) showed prolonged periods and recorded 1.77, 2.22, and 3 days with control, $\mathrm{LC}_{5}$, and $\mathrm{LC}_{15}$, respectively. Similarly, the total preovipositional period (TPOP) showed 29.66, 31.44, and 32.11 days with control, $\mathrm{LC}_{5}$, and $\mathrm{LC}_{15}$, respectively. On the other hand, EMB sublethal concentrations reduced the ovi-days period from 5.17 days for control to 4.67 days and 3.57 days for $\mathrm{LC}_{5}$ and $\mathrm{LC}_{15}$ treatments, respectively.

\section{Effect of sublethal concentrations on population growth parameters}

Sublethal concentrations of EMB showed pronounce effects on S. littoralis population life table parameters (Table 3). Intrinsic rate of increase $(r)$, net reproduction rate $\left(R_{0}\right)$, finite rate of increase $(\lambda)$, gross reproductive rate (GRR), mean generation time $(T)$, doubling time (DT), and fecundity were affected by EMB treatment. Intrinsic rate of increase $(r)$ decreased for both $\mathrm{LC}_{5}$ and $\mathrm{LC}_{15}\left(0.174\right.$, and 0.161 day $^{-1}$, respectively), compared with the control $\left(0.208 \mathrm{day}^{-1}\right)$. The finite rate of increase $(\lambda)$ showed a similar trend and recorded 1.230, 1.190, and 1.175 day $^{-1}$ for control, $\mathrm{LC}_{5}$, and $\mathrm{LC}_{15}$, respectively. Gross reproductive rate (GRR) was varied significantly in treatments than control recording $1197.05,514.13$, and 451.34 for control, $\mathrm{LC}_{5}$, and $\mathrm{LC}_{15}$, respectively. Similarly, the net reproductive rate significantly decreased after emamectin benzoate treatment recording 959.11, 368.23, and 264.90 offspring/individual for control, $\mathrm{LC}_{5}$, and $\mathrm{LC}_{15}$, respectively. Similarly, the mean fecundities recorded 2038.12, 1043, and 965 per female in control, $\mathrm{LC}_{5}$ and $\mathrm{LC}_{15}$, respectively. In contrast, the mean generation time and the doubling time recorded increased values with EMB treatments. The mean generation time $(\mathrm{T})$ of treated individuals was longer than control larvae $(32.99,33.83$, and 34.57 days in control, $\mathrm{LC}_{5}$ and $\mathrm{LC}_{15}$, respectively). The doubling time (DT) is the time period required to redouble a certain population. The obtained data showed that doubling time increased with increasing the used sublethal concentration recording 3.33, 3.97, and 4.30 for control, $\mathrm{LC}_{5}$, and $\mathrm{LC}_{15}$ treatments, respectively.

Age-stage specific survival rate $\left(S_{x j}\right)$ of insects expresses the survival potential of newly hatched larvae to the age $x$ and stage $j$. Stages overlap observed in Fig. 1 interpreted, as a result to individuals variations in developmental rates. Figure 1 declares that $\mathrm{LC}_{5}$ and $\mathrm{LC}_{15}$ treatments declined relative numbers of alive larvae compared with controls, while $\mathrm{LC}_{5}$ and $\mathrm{LC}_{15}$ treatments increased total development compared with control.

Table 2 Effect of emamectin benzoate (EMB) sublethal concentrations on various biological characteristics of Spodoptera littoralis

\begin{tabular}{|c|c|c|c|c|c|c|c|c|c|c|}
\hline \multirow[t]{2}{*}{ Stages } & \multicolumn{2}{|c|}{ Untreated } & \multicolumn{2}{|l|}{$\mathrm{LC}_{5}$} & \multicolumn{2}{|c|}{$\mathrm{LC}_{15}$} & \multirow[t]{2}{*}{$\mathrm{df}_{1}$} & \multirow[t]{2}{*}{$\mathrm{df}_{2}$} & \multirow[t]{2}{*}{$F$} & \multirow[t]{2}{*}{$P$} \\
\hline & $n$ & Mean \pm SE & $n$ & Mean \pm SE & $\bar{n}$ & Mean \pm SE & & & & \\
\hline Larvae period & 86 & $15.41 \pm 0.07^{\mathrm{a}}$ & 80 & $16.98 \pm 0.08^{b}$ & 70 & $16.86 \pm 0.07^{b}$ & 2 & 233 & 280.16 & 0.00 \\
\hline Pre-pupae weight & 84 & $344.62 \pm 6.43^{a}$ & 76 & $305.13 \pm 6.14^{b}$ & 70 & $294.85 \pm 6.28^{b}$ & 2 & 227 & 915.89 & 0.00 \\
\hline Pupae weight & 84 & $324.17 \pm 6.46^{a}$ & 74 & $273.08 \pm 6.29^{b}$ & 60 & $266.40 \pm 4.15^{b}$ & 2 & 215 & 4365.92 & 0.00 \\
\hline Pupae period & 84 & $10.16 \pm 0.13^{\mathrm{a}}$ & 74 & $9.24 \pm 0.11^{b}$ & 60 & $9.23 \pm 0.09^{b}$ & 2 & 215 & 43.42 & 0.00 \\
\hline Mean longevity of males (days) & 36 & $37.79 \pm 0.18^{\mathrm{a}}$ & 38 & $39.05 \pm 0.36^{b}$ & 32 & $38.88 \pm 0.36^{c}$ & 2 & 103 & 9.03 & 0.00 \\
\hline Mean longevity of females (days) & 48 & $38.5 \pm 0.25^{\mathrm{a}}$ & 36 & $40.11 \pm 0.35^{b}$ & 28 & $39.99 \pm 0.33^{b}$ & 2 & 109 & 20.70 & 0.00 \\
\hline (APOP) & 48 & $1.67 \pm 0.14^{a}$ & 36 & $2.22 \pm 0.15^{b}$ & 28 & $3.07 \pm 0.4^{c}$ & 2 & 109 & 20.78 & 0.00 \\
\hline (TPOP) & 48 & $30.04 \pm 0.14^{\mathrm{a}}$ & 36 & $31.44 \pm 0.26^{b}$ & 28 & $32.21 \pm 0.37^{b}$ & 2 & 109 & 45.12 & 0.00 \\
\hline Ovi-days & 48 & $5.17 \pm 0.37^{\mathrm{a}}$ & 36 & $4.67 \pm 0.28^{a}$ & 28 & $3.57 \pm 0.23^{b}$ & 2 & 109 & 64.31 & 0.00 \\
\hline
\end{tabular}

$A P O P$ adult preovipositional period, TPOP total preovipositional period (from egg to first oviposition)

Means in the same row followed by the same letter are not significantly different $(P>0.05)$

df1, degree of freedom within groups

$\mathrm{df2}$, degree of freedom within groups 
Table 3 The sublethal effects of emamectin benzoate on S. littoralis population parameters

\begin{tabular}{llll}
\hline & Untreated & $L C_{5}$ & $L_{15}$ \\
\hline Net reproductive rate $\left(R_{0}\right)$ (offspring/individual) & $958.74 \pm 169.19^{\mathrm{a}}$ & $368.235 \pm 73.300^{\mathrm{b}}$ & $264.90 \pm 66.103^{\mathrm{b}}$ \\
Intrinsic rate of increase $(r)\left(d^{-1}\right)$ & $0.208 \pm 0.006^{\mathrm{a}}$ & $0.174 \pm 0.006^{\mathrm{b}}$ & $0.161 \pm 0.007^{\mathrm{b}}$ \\
Finite rate of increase $(\lambda)\left(d^{-1}\right)$ & $1.231 \pm 0.006^{\mathrm{a}}$ & $1.190 \pm 0.007^{\mathrm{b}}$ & $1.175 \pm 0.009^{\mathrm{b}}$ \\
Mean generation time $T(d)$ & $32.99 \pm 0.178^{\mathrm{a}}$ & $33.83 \pm 0.205^{\mathrm{b}}$ & $34.57 \pm 0.216^{\mathrm{c}}$ \\
The doubling time (DT) & 3.33 & 3.97 & 4.3 \\
Fecundity (eggs/female) & $2038.12 \pm 194.216^{\mathrm{a}}$ & $1043.33 \pm 62.977^{\mathrm{b}}$ & $965 \pm 103.09^{\mathrm{b}}$ \\
Gross reproductive rate (GRR) & $1197.05 \pm 193.06^{\mathrm{a}}$ & $514.13 \pm 91.52^{\mathrm{b}}$ & $451.34 \pm 100.32^{\mathrm{b}}$ \\
Relative fitness & 1 & 0.38 & 0.28 \\
\hline
\end{tabular}

Means in the same row followed by the same letter are not significantly different $(P>0.05)$

Finite rate of increase $(\lambda)(d-1)$, the number of females per female per day

Gross reproductive rate (GRR), defines as total lifetime reproduction in the absence of mortality
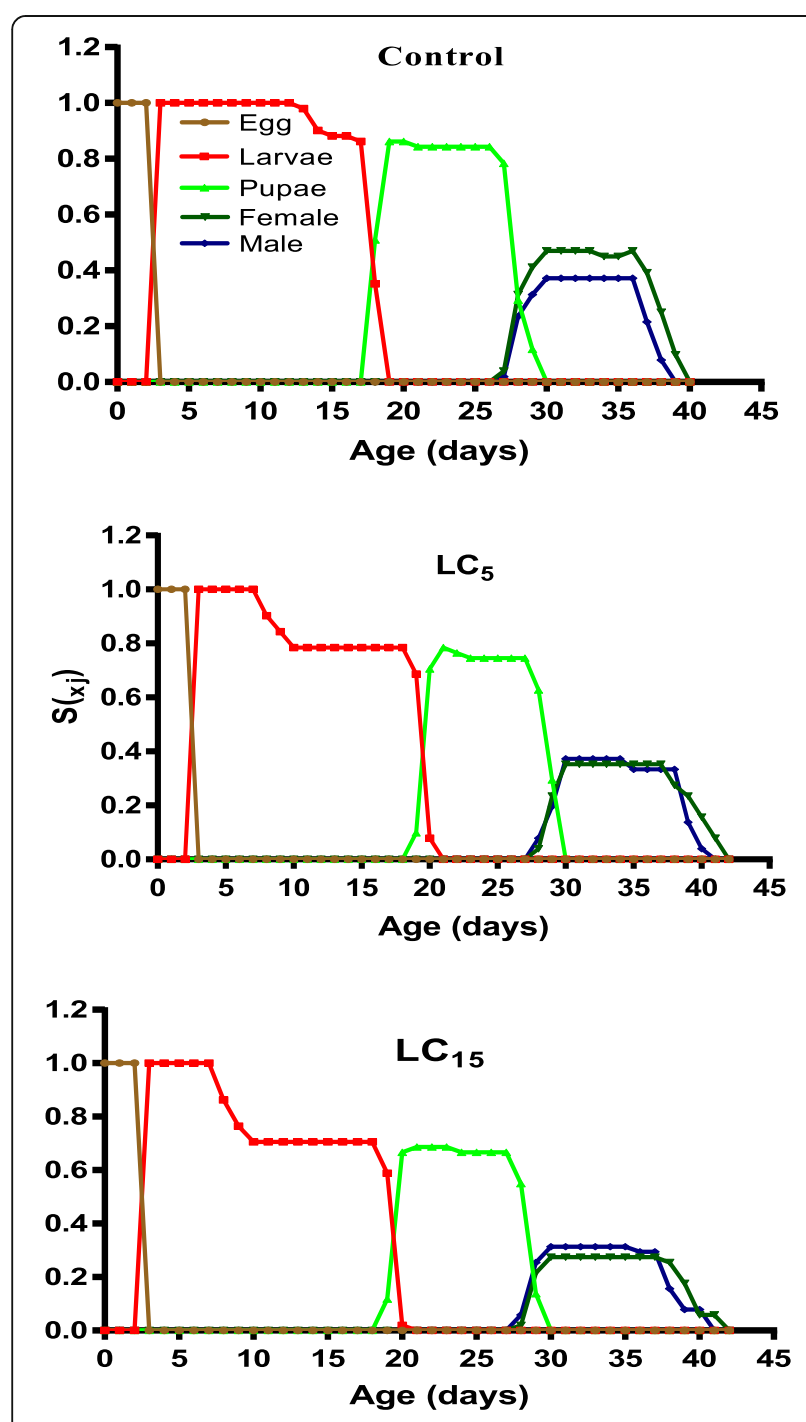

Fig. 1 Age-stage specific survival rate $\left(S_{x j}\right)$ of $S$. littoralis exposed to sublethal concentrations of EMB
Age-stage specific reproductive value $\left(V_{\mathrm{x}, \mathrm{j}}\right)$ indicates the status of future offspring from age $x$ to stage $j$ (Fig. 2). The males curve was not included in $V_{x, j}$ graph because males contribution in future population was not defined. $V_{x, j}$ values declined in $\mathrm{LC}_{5}$ and $\mathrm{LC}_{15}$ treated larvae compared with the control group.

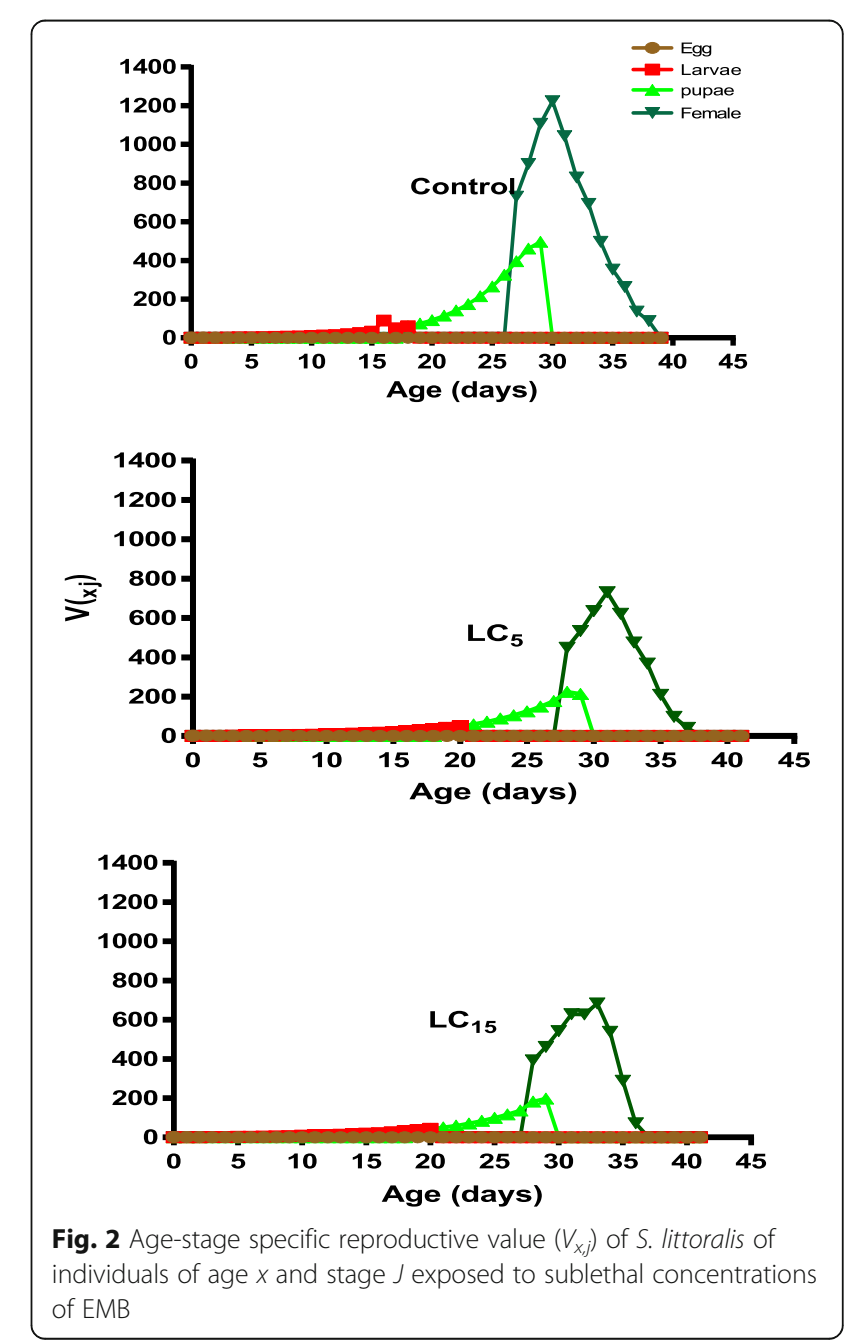


The age-specific survival rate $\left(l_{x}\right)$, female age-specific fecundity $\left(f_{x 4}\right)$, age-specific fecundity $\left(m_{x}\right)$, and agespecific maternity $\left(l_{x} m_{x}\right)$ are presented in Fig. 3. Agespecific survival rate $\left(l_{x}\right)$ is the probability of a newly hatched larva to survive to age $x . l_{x}$ simply expressed the age-stage survival rate $\left(S_{x j}\right)$. The $l_{x}$ avoids the overlapping phenomenon observed in $S_{x j}$ due to an individual's differences in developmental rates (Fig. 1). The curves of $l_{x}$ declined significantly in treated larvae compared with control, and consequently sublethal concentrations of EMB proved a higher impact on larval mortality. Agespecific fecundity of the total population $\left(m_{x}\right)$ showed the highest peaks in the control group than the $\mathrm{LC}_{5}$ and $\mathrm{LC}_{15}$ groups.

\section{Discussion}

Sublethal effects defined as physiological, behavioral, and survival responses after exposure to a sublethal amount of toxic compound (Tao and Wu 2006; Desneux et al. 2007). These effects resulted due to either attack the nervous system or disrupt hormonal balance (Moustafa et al. 2016). Exposure to sublethal concentrations results from either variable insecticides distribution or continuous degradation (Biondi et al. 2012; Tang et al. 2015).

The present work investigated the sublethal effects of EMB against S. littorals. EMB showed high toxicity against $S$. littoralis consistent with other previous findings of Mokbel et al. (2017). The first larval instar of $S$. littoralis treated with $\mathrm{LC}_{5}$ and $\mathrm{LC}_{15}$ of $\mathrm{EMB}$ showed a significant increase in the larval period compared with control. Extended larval duration has interpreted as a result of either larval starvation or increasing consumed energy. As many pesticides reduce nutrition efficiency and increase larval consumption of energy in detoxification processes (Lai and Li 2011; Xu et al. 2016). The previous reasons can also interpret the reduction in pre-

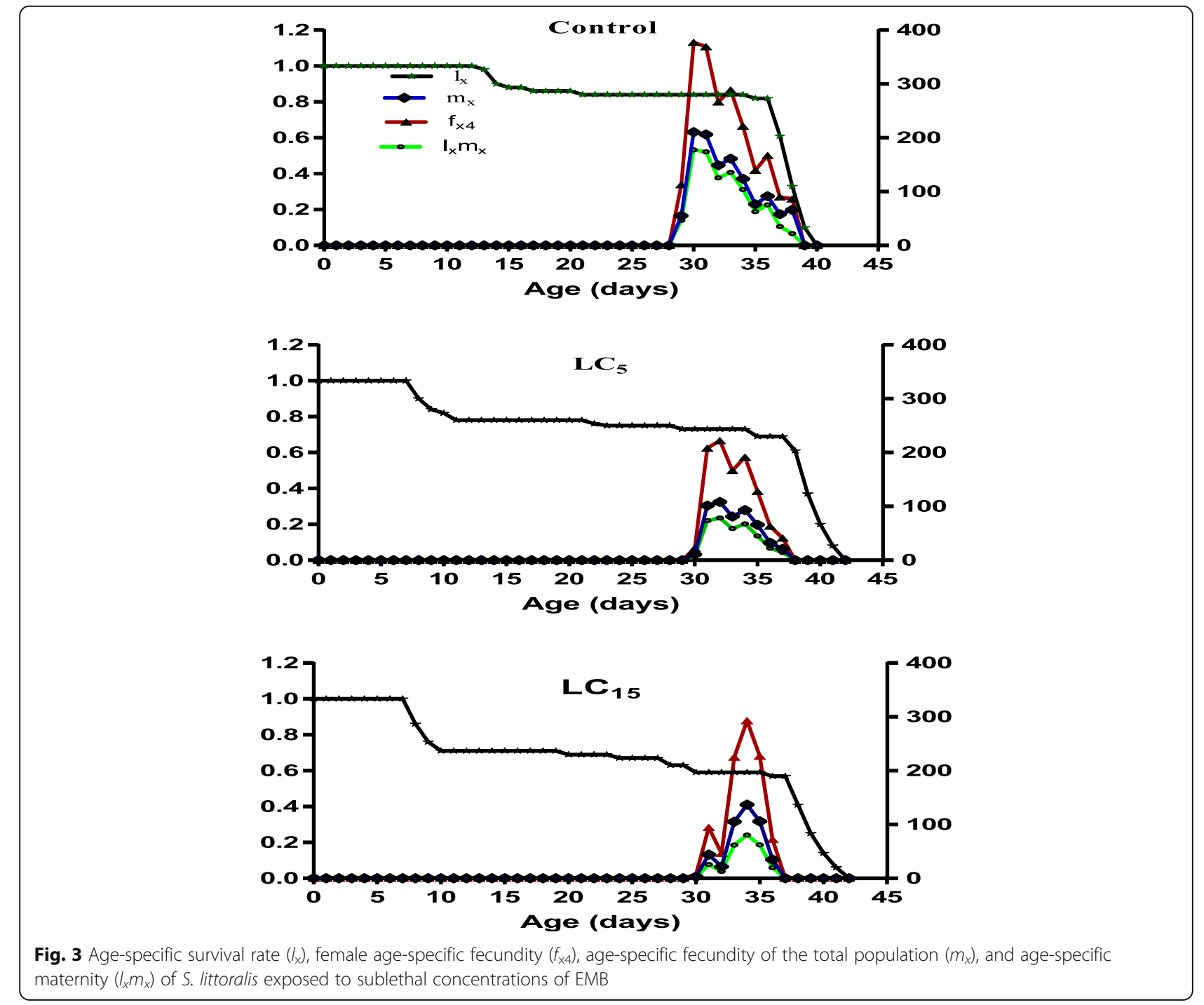


pupae and pupae weight in treated larvae. The sublethal effects were investigated with several insects includes the cotton leafworms, S. littoralis (El-Naggar Jehan 2013; Metayi et al. 2015), the diamondback moth, Plutella xylostella L. (Plutellidae: Lepidoptera) (Guo et al. 2013), the cabbage aphid, Brevicoryne brassicae (Aphididae: Hemiptera) (Lashkari and Sahragard 2007), and whitefly, Bemisia tabaci (Hemiptera: Aleyrodidae) (He et al. 2013).

Life table studies have been used to assess the effects of different variables on insect population dynamics (Rahmani and Bandani 2013). Life table parameters such as the intrinsic rate of increase, net reproductive rate, and total preoviposition period can be used to determine population growth characteristics (Papachristos and Milonas 2008; Rahmani and Bandani 2013). The current study exhibited the ability of sublethal concentrations of EMB to decrease life table parameters such as intrinsic rates of increase $(r)$, finite rates of increase $(\lambda)$, net reproduction rate $\left(R_{0}\right)$, gross reproductive rate (GRR), survival rate, and reproductive value. In contrast, mean generation time $(\mathrm{T})$, doubling time $(\mathrm{DT})$, adult preovipositional period (APOP), total preovipositional period (TPOP), and larval durations were prolonged by treatments. Consequently, sublethal concentrations of EMB inhibited S. littoralis population growth. Several reports confirmed the inhibitory effect of sublethal concentration of EMB on several insects include S. littoralis (ElNaggar Jehan 2013; Metayi et al. 2015). Other insects showed similar trends after treatment with sublethal concentrations of different insecticides including the cabbage moth, Mamestra brassicae L. (Lepidoptera: Noctuidae) (Moustafa et al. 2016), the house fly, Musca domestica L. following the treatment with Cantharidin (Yasoob et al. 2017) and the chive gnat, Bradysia odoriphaga after treatment with thiamethoxam (Zhang et al. 2014b), the seven-spot ladybeetle Coccinella septempunctata L. (Coleoptera: Coccinellidae) (Jiang et al. 2019). Similar findings observed with sulfoxaflor on the mirid bug, Apolygus lucorum (Meyer-Dür) (Heteroptera: Miridae) (Zhen et al. 2018).

Survival rate describes survivorship and stage transitions of insects, varies in different conditions and within different insect species. Results indicated that the number of alive larvae was reduced by the $\mathrm{LC}_{5}$ and further reduction followed the $\mathrm{LC}_{15}$ treatment. Furthermore, the Age-stage specific survival rate $\left(s_{x j}\right)$ was decreased with EMB sublethal concentrations. These results are in line with that obtained with (Zhang et al. 2014b) for the sublethal effects of thiamethoxam on Bradysia odoriphaga (Yang and Zhang). Also, fecundity parameters which include age-specific fecundity $\left(f_{x 4}\right)$, age-specific maternity $\left(l_{x} m_{x}\right)$, and reproduction value $\left(V_{x j}\right)$ were decreased in treatments compared with control. These results indicate the potential of sublethal concentrations of EMB to decrease the biological productivity of S. littoralis. Low fecundity of the treated groups may interpret a result of either ovaries immaturities (Perveen 2000) or inhibiting the production of nymphs (Devine et al. 1996).

Laboratory experiment of sublethal effect provides a good vision to insect population dynamic and can be used to develop a pest control strategy (Chi and $\mathrm{Su}$ 2006). The current study explains the role of sublethal concentrations in suppressing insect population growth. Furthermore, integrate such concentrations in pest control programs to decrease pesticide selection pressure, pesticide amount, control costs, and environmental pollution (Zhang et al. 2014). The present study showed that EMB sublethal concentrations affecting various biological aspects and life table parameters, and consequently, decreased population growth. So, the current results fortified the role of such concentrations in pest management.

\section{Conclusions}

The study proved the pronounced effects of EMB sublethal concentrations on biological aspects and population growth of the cotton leafworm population. These concentrations strongly suppressed S. littoralis. These findings can contribute in planning pest management programs, concepting the future use of the pesticide, and using of these sublethal concentrations in pest management.

\section{Abbreviations \\ EMB: Emamectin benzoate; T: Mean generation time; DT: Doubling time; APOP: Adult preovipositional period; TPOP: Total preovipositional period; $R_{0}$ : Net reproduction rates; $r$ : Intrinsic rates of increase; $\lambda$ : Finite rate; GRR: Gross reproductive rate; $S_{x ;}$ : Age-stage specific survival rate; $V_{x j}$ : Age- stage specific reproductive value; $l_{x}$ : The age-specific survival rate; $m_{x}$ : Age- specific fecundity; $f_{x 4}$ : Female age-specific fecundity; $I_{x} m_{x}$ : Age-specific maternity}

\section{Acknowledgements \\ The authors thank Dr. Eman Atef Fouad-Department of Bioassay, Central Agricultural Pesticides Laboratory, Agricultural Research Center for her critical reviewing for the manuscript.}

\section{Authors' contributions}

Dr. Amal contributed in the study design and experimental work. Dr. Sayed was a major contributor in designing the study, conducting the experimental part, and analyzing the obtained data. All authors read and approved the final manuscript.

\section{Funding}

There was no funding for this work.

\section{Availability of data and materials}

All data generated during this study are included in this published article.

\section{Ethics approval and consent to participate}

The manuscript does not contain any studies involving human participants, human data, or human tissue.

Consent for publication

Not applicable. 


\section{Competing interests}

The authors declare that they have no competing interests.

Received: 23 July 2020 Accepted: 27 August 2020

Published online: 10 September 2020

\section{References}

Abbott WS (1925) A method of computing the effectiveness of an insecticide. J Econ Entomol 18:265-267 https://doi.org/10.1093/jee/18.2.265a

Barrania AA (2019) Effects of some insecticides on some biological parameters of cotton leafworm, Spodoptera littoralis (Lepidoptera: Noctuidae). Alexandria Sci Exch J 40:307-313 https://doi.org/10.21608/asejaiqjsae.2019.34182

Biondi A, Desneux N, Siscaro G, Zappalà L (2012) Using organic-certified rather than synthetic pesticides may not be safer for biological control agents: selectivity and side effects of 14 pesticides on the predator Orius laevigatus. Chemosphere 87:803-812

Chi H (2012) TWOSEX-MS Chart: a computer program for the age-stage, two-sex life table analysis Available from http://140.120. 197.173/Ecology/Download. Tw osex-MSChart. zip.

Chi H, Getz WM (1988) Mass rearing and harvesting based on an age-stage, twosex life table: a potato tuberworm (Lepidoptera: Gelechiidae) case study. Environ Entomol 17:18-25

Chi H, Su H (2006) Age-stage, two-sex life tables of Aphidius gifuensis (Ashmead) (Hymenoptera: Braconidae) and its host Myzus persicae (Sulzer) (Homoptera: Aphididae) with mathematical. Environ. Entomol. 10-21. https://doi.org/ 0046-25X/06/0010Đ0021\$04.00/0

Cor IBMS (2016) IBM SPSS statistics for windows, version 24.0. Armonk IBM Corp.

Desneux N, Decourtye A, Delpuech JM (2007) The sublethal effects of pesticides on beneficial arthropods. Annu Rev Entomol 52:81-106 https://doi.org/10. 1146/annurev.ento.52.110405.091440

Devine GJ, Harling ZK, Scarr AW, Devonshire AL (1996) Lethal and sublethal effects of imidacloprid on nicotine-tolerant Myzus nicotianae and Myzus persicae. Pestic Sci 48:57-62

Egyptian Agricultural Pesticides Committee (2019) http://www.apc.gov.eg.

El-Naggar Jehan BA (2013) Sublethal effect of certain insecticides on biological and physiological aspects of Spodoptera littoralis (Boisd.). Nat Sci 11:19-25

Finney DJ (1971) Probit analysis. 1971. New York, Ny 10022, 32.

Forbes VE, Calow P (1999) Is the per capita rate of increase a good measure of population-level effects in ecotoxicology? Environ Toxicol Chem 18:15441556

Guo L, Desneux N, Sonoda S, Liang P, Han P, Gao XW (2013) Sublethal and transgenerational effects of chlorantraniliprole on biological traits of the diamondback moth. Plutella xylostella L Crop Prot 48:29-34

He Y, Zhao J, Zheng Y, Weng Q, Biondi A, Desneux N, Wu K (2013) Assessment of potential sublethal effects of various insecticides on key biological traits of the tobacco whitefly, Bemisia tabaci. Int. J. Biol. Sci. 9, 246-255. https://doi. org/10.7150/ijbs.5762

Hosny MM, Topper CP, Moawad GM, El-Saadany GB (1986) Economic damage thresholds of Spodoptera littoralis (Boisd.) (Lepidoptera: Noctuidae) on cotton in Egypt. Crop Prot. 5, 100-104. https://doi.org/10.1016/0261-2194(86)90088-8

Ishaaya I, Kontsedalov S, Horowitz AR (2002) Emamectin, a novel insecticide for controlling field crop pests. Pest Manag Sci 58:1091-1095 https://doi.org/10. 1002/ps.535

Jiang J, Zhang Z, Yu X, Yu C, Liu F, Mu W (2019) Sublethal and transgenerational effects of thiamethoxam on the demographic fitness and predation performance of the seven-spot ladybeetle Coccinella septempunctata $\mathrm{L}$. (Coleoptera: Coccinellidae). Chemosphere 216:168-178 https://doi.org/10. 1016/j.chemosphere.2018.10.126

Kareiva P, Stark J, Wennergren U (1996) Using demographic theory, community ecology and spatial models to illuminate ecotoxicology, in: Ecotoxicology: Ecological Dimensions. Springer, pp. 13-23.

Lai T, Li SJ (2011) Monitoring of beet armyworm Spodoptera exigua (Lepidoptera: Noctuidae) resistance to chlorantraniliprole in China. Pestic Biochem Physio 101:198-205

Lashkari MR, Sahragard A (2007) Sublethal effects of imidacloprid and pymetrozine on population growth parameters of cabbage aphid, Brevicoryne brassicae on rapeseed, Brassica napus L. Insect Sci.;14(3):20712207-212. https://doi.org/10.1111/j.1744-7917.2007.00145.x

Metayi MHA, Ibrahiem MAM, El-deeb DA (2015) Toxicity and some biological effects of emamectin benzoate, novaluron and diflubenzuron against cotton leafworm. Alex Sci Exch J 36(4):350-357
Mokbel EMS, Huesien Al, Abdel-Hamid HFM, Osman H (2017) Assessment of resistance risk to emamectin benzoate, indoxacarb and spinetoram in cotton leaf worm, Spodoptera littoralis (Boisd.). Egypt. Acad J Biol Sci 9(1):9-18

Mokbel EMS, Fouad E, SAN E-S (2019) Resistance monitoring of cotton leaf worm, Spodoptera littoralis (Boisduval) (Lepidoptera: Noctuidae) against certain alternative insecticides of four different field populations in Egypt. J Biol ChemEnviron Sci 14(1):319-333

Moustafa MAM, Kákai Á, Awad M, Fónagy A (2016) Sublethal effects of spinosad and emamectin benzoate on larval development and reproductive activities of the cabbage moth, Mamestra brassicae L. (Lepidoptera: Noctuidae). Crop Prot 90:197-204

Osman M, Mahmoud M (2009) Effects of bio-rational insecticides on selected biological aspects of the Egyptian cotton leafworm Spodoptera littoralis (Boisd.) (Lepidoptera: Noctuidae). J. Plant Prot. Res. 49:135-140 https://doi. org/10.2478/v10045-009-0018-0

Papachristos DP, Milonas PG (2008) Adverse effects of soil applied insecticides on the predatory coccinellid Hippodamia undecimnotata (Coleoptera: Coccinellidae). Biol Control 47:77-81

Perveen F (2000) Sublethal effects of on reproductivity and viability of Spodoptera litura (F.) (Lep., Noctuidae). J Appl Entomol 24:223-231 https://doi.org/10. 1046/j.1439-0418.2000.00468.x

Pineda S, Schneider MI, Smagghe G, Martínez AM, Del Estal P, Viñuela E, Valle J, Budia F (2007) Lethal and sublethal effects of methoxyfenozide and spinosad on Spodoptera littoralis (Lepidoptera: Noctuidae). J Econ Entomol 100(3):773780

Quan L, Qiu G, Zhang H, Sun L, Li Y (2016) Insecticide resistance and resistance management sublethal concentration of beta-cypermethrin influences fecundity and mating behavior of Carposina sasakii (Lepidoptera: Carposinidae) adults. J Econ Entomol 109(5):2196-2204 https://doi.org/10. 1093/jee/tow170

Rahmani S, Bandani AR( 2013) Sublethal concentrations of thiamethoxam adversely affect life table parameters of the aphid predator, Hippodamia variegata (Goeze) (Coleoptera: Coccinellidae). Crop Prot. 54, 168-175. https:// doi.org/10.1016/j.cropro.2013.08.002

Rehan A, Freed S( 2015) Fitness cost of methoxyfenozide and the effects of its sublethal doses on development, reproduction, and survival of Spodoptera litura (Fabricius) (Lepidoptera: Noctuidae). Neotrop. Entomol. 44, 513-520. https://doi.org/10.1007/s13744-015-0306-5

Rezaei M, Talebi K, Naveh VH, Kavousi A (2007) Impacts of the pesticides imidacloprid, propargite, and pymetrozine on Chrysoperla carnea (Stephens) (Neuroptera: Chrysopidae): IOBC and life table assays. BioControl 52, 385-398. https://doi.org/10.1007/s10526-006-9036-2

Shen J, Li D, Zhang S, Zhu X, Wan H, Li J (2017) Fitness and inheritance of metaflumizone resistance in Plutella xylostella. Pestic Biochem Physiol 139:5359

Stark JD, Tanigoshi L, Bounfour M, Antonelli A (1997) Reproductive potential: its influence on the susceptibility of a species to pesticides. Ecotoxicol Environ Saf 37:273-279 https://doi.org/10.1006/eesa.1997.1552

Tang Q, Xiang M, Hu H, An C, Gao X (2015) Evaluation of sublethal effects of sulfoxaflor on the green peach aphid (Hemiptera: Aphididae) using life table parameters. J Econ Entomol 108:2720-2728 https:/doi.org/10.1093/jee/tov221

Tao S, Wu F (2006) Sublethal effect of chlorpyrifos on dynamics of experimental Tetranychus cinnabarinus population. Ying yong sheng tai xue bao $=J$. Appl Ecol 17:1351-1353

Xu C, Zhang Z, Cui K, Zhao Y, Han J, Liu F, Mu W (2016) Effects of sublethal concentrations of cyantraniliprole on the development, fecundity and nutritional physiology of the black cutworm Agrotis ipsilon (Lepidoptera: Noctuidae). PLoS One 1-11:e0156555 https://doi.org/10.1371/journal.pone. 0156555

Yasoob H, Ali Khan HA, Zhang Y (2017) Toxicity and sublethal effects of cantharidin on Musca domestica (Diptera: Muscidae). J Econ Entomol 110: 2539-2544 https://doi.org/10.1093/jee/tox205

Zanuncio TV, Zanuncio JC, Serrão JE, Medeiros RS, Pinon T, Sediyama CAZ (2005) Fertility and life expectancy of the predator Supputius cincticeps (Heteroptera: Pentatomidae) exposed to sublethal doses of permethrin. Biol Res 38:31-39

Zhang P, Liu F, Mu W, Wang Q, Li H (2014a) Comparison of Bradysia odoriphaga Yang and Zhang reared on artificial diet and different host plants based on an age-stage, two-sex life table. Phytoparasitica 43:107-120 https://doi.org/ 10.1007/s12600-014-0420-7

Zhang P, Liu F, Mu W, Wang Q, Li H, Chen C (2014b) Life table study of the effects of sublethal concentrations of thiamethoxam on Bradysia odoriphaga 
Yang and Zhang. Pestic. Biochem. Physiol. 111, 31-37. https://doi.org/10. 1016/j.pestbp.2014.04.003

Zhen C, Miao L, Gao X (2018) Sublethal effects of sulfoxaflor on biological characteristics and vitellogenin gene (AlVg) expression in the mirid bug, Apolygus lucorum (Meyer-Dür). Pestic. Biochem. Physiol. 144, 19-26. https:// doi.org/10.1016/j.pestbp.2017.11.008

\section{Publisher's Note}

Springer Nature remains neutral with regard to jurisdictional claims in published maps and institutional affiliations.

Submit your manuscript to a SpringerOpen ${ }^{\circ}$ journal and benefit from:

- Convenient online submission

- Rigorous peer review

- Open access: articles freely available online

- High visibility within the field

- Retaining the copyright to your article

Submit your next manuscript at $\boldsymbol{\wedge}$ springeropen.com 